\title{
MED27 wt Allele
}

National Cancer Institute

\section{Source}

National Cancer Institute. MED27 wt Allele. NCI Thesaurus. Code C52211.

Human MED27 wild-type allele is located in the vicinity of 9q34.3 and is approximately $220 \mathrm{~kb}$ in length. This allele, which encodes mediator of RNA polymerase II transcription subunit 27 protein, plays an essential role in transcriptional progression. 